\title{
Langkah Manajerial Kepala Sekolah dalam Meningkatkan Kompetensi Guru Agama Islam di Madrasah Aliyah Muhammadiyah Curup
}

\author{
Lukman Asha \\ Institut Agama Islam Negeri (IAIN) Curup, Indonesia \\ asha.lukman@gmail.com
}

\begin{abstract}
Law No. 14 of 2005 concerning Teachers and Lecturers, has inspired the Principal of the Madrasah Aliyah Muhammadiyah School (MAM) Curup. The inspiration was manifested in the managerial step of increasing four main competencies, namely: pedagogical competence, professional competence, personality competence, and social competence. In connection with the managerial step, this paper aims to describe; (1) school principal management in improving teacher competency; (2) the success of the principal's management in improving teacher competency; (3) inhibiting factors and principals management solutions in improving teacher competency. This research is in the form of qualitative, using data collection methods in the form of observation, interviews, and documentation. The results showed that the principal's management strategy in improving teacher competency in MAM Curup, namely: First, School Principal Management in improving Islamic education teacher competencies as follows: (1) Involving teachers in training, training and seminars, (2) Promoting discipline, (3) Motivating teachers, through motivation from school principals, becomes the spirit for teachers to improve improvements in educational innovation as a tangible form of developing competencies, (4) Implementation of Supervision. Secondly, the application of the principal's management in improving teacher competence greatly influences the competency of PAI teachers in MAM Curup, namely that teachers have implemented the five basic competency standards that are best governed by the government. Third, the barriers and solutions of the principal's management in developing the competence of Islamic education teachers in MAM Curup, namely: The role of parents has not been seen in the personal / karaker of each student, then together with the teaching time of the teacher with the training time in increasing teacher competency.
\end{abstract}

Keywords: Management, Principal, MAM Curup

FOKUS : Jurnal Kajian Keislaman dan Kemasyarakatan Vol. 4, No. 2, 2019

LPPM Institut Agama Islam Negeri (IAIN) Curup - Bengkulu

Available online: http://journal.staincurup.ac.id/index.php/JF

p-ISSN 2548-334X, e-ISSN 2548-3358 


\begin{abstract}
Abstrak
Lahirnya UU No. 14 tahun 2005 tentang Guru dan Dosen, telah menginspirasi Kepala Sekolah Madrasah Aliyah Muhammadiyah (MAM) Curup. Inspirasi itu terwujud dalam langkah manajerial peningkatan empat kompetensi utama yakni: kompetensi pedagogis, kompetensi profesional, kompetensi kepribadian, dan kompetensi sosial. Sehubungan dengan langkah menejerial tersebut, tulisan ini bertujuan untuk mendeskripsikan; (1) manajemen kepala sekolah dalam meningkatkan kompetensi guru; (2) keberhasilan manajemen kepala sekolah dalam meningkatkan kompetensi guru; (3) faktor penghambat dan solusi manajemen kepala sekolah dalam meningkatkan kompetensi guru. Penelitian ini berbentuk kualitatif, menggunkan metode pengumpulan data berupa observasi, wawancara, dan dokumentasi. Hasil penelitian menunjukkan bahwa strategi manajemen kepala sekolah dalam meningkatkan kompetensi guru di MAM Curup, yaitu: Pertama, Manajemen Kepala Sekolah dalam meningkatkan kompetensi guru pendidikan Islam sebagai berikut: (1) Mengikutkan guru dalam diklat, pelatihan dan seminar, (2) Mengedepankan kedisiplinan, (3) Memotivasi guru, melalui motivasi dari kepala sekolah menjadi semangat bagi guru untuk meningkatkan perbaikan dalam inovasi pendidikan sebagai wujud nyata mengembangkan kompetensi, (4) Pelaksanaan Supervisi. Kedua, penerapan dari manajemen kepala sekolah dalam meningkatkan kompetensi guru sangat berpengaruh kepada kompetensi guru PAI di MAM Curup, yaitu bahwa para guru sudah menerapkan kelima standar kompetensi dasar yang diatur oleh pemerintah dengan sebaik-baiknya. Ketiga, Hambatan dan solusi manajemen kepala sekolah dalam mengembangkan kompetensi guru pendidikan Islam di MAM Curup, yakni: Peran orang tua belum tampak pada pribadi/karaker masing-masing peserta didik, kemudian bersamaannya waktu mengajar guru dengan waktu pelatihan-pelatihan dalam meningkatkan kompetensi guru.
\end{abstract}

Katakunci: Manajemen, Kepala Sekolah, MAM Curup

\title{
PENDAHULUAN
}

Pendidikan memiliki peran penting untuk memajukan suatu bangsa, pendidikan merupakan wahana dalam meningkatkan kualitas sumber daya manusia secara universal. Lembaga pendidikan secara kontinunitas mengalami kemajuan dari generasi kegenerasi bergerak berubah dan berkembang menuju kualitas yang lebih baik.

Perkembangan ilmu pengetahuan dan teknologi secara otomatis menuntut lembaga pendidikan untuk menyesuaikan terhadap kondisi tersebut 
dalam mencetak output berkualitas yang memiliki kreativitas, bakat dan motivasi belajar serta wawasan luas pada bidang ilmu yang ditekuni serta terampil secara aflikasi dalam menggunakan keilmuannya serta siap berkompetisi dalam kancah global.

Dengan otonomi daerah pemerintah memberi kesempatan sepenuhnya kepada pihak sekolah untuk mengelola sekolah secara mandiri sesuai dengan kemampuan dan potensi sekolah tersebut. Seiring terjadinya perubahan manajemen sekolah dimana fokusnya terhadap kebutuhan peserta didik dan stakeholders pendidikan. Maka orientasi pembelajaran juga mengalami perubahan dari kegiatan belajar yang berpusat pada guru (teachers centread learning) menuju pembelajaran berpusat kepada siswa (students centread learning).

Permasalah kompetisi pendidikan di Indonesia menyangkut setiap jenjang pendidikan, termasuk didalamnya jenjang pendidikan menengah atas. Walapun upaya-upaya peningkatan kompetensi pendidikan telah dilakukan dengan mengusung 4 (empat) kebijakan strategis yaitu; pemerataan kesempatan, peningkatan relevansi, mutu dan efisiensi pendidikan. ${ }^{1}$ Ternyata dalam realitas implementasinya pihak sekolah belum mampu melakukan berbagai inovasi baik pada aspek sistem pembelajaran maupun kualitas pembelajaran, sungguh masih perlu perbaikan dan peningkatan.

Selain itu peningkatan kompetensi pendidikan merupakan bagian yang tidak terpisahkan dari proses pengembangan sumber daya manusia. Upaya tersebut harus dilakukan secara terencana, terarah, dan intensip, sehingga mampu menyiapkan bangsa Indonesia memasuki era persainagan yang sangat kompetitip ini. UU Nomor 20 tahun 2003 menjelaskan bahwa pendidikan memiliki fungsi meningkatkan potensi peserta didik agar menjadi manusia yang beriman dan bertakwa kepada Tuhan Yang Maha Esa, berakhlak mulia, sehat, berilmu, cakap, kreatif, mandiri dan menjadi warga negara yang demokratis serta bertanggung jawab. ${ }^{2}$

Keberhasilan kepala sekolah dalam melaksanakan tugasnya tergantung manajemennya. Efektipitas pengelolaan bidang garapan sekolah dan kegiatan pembinaan erat kaitannya dengan efektifitas kerja personal sekolah. Apabila kepala sekolah mampu menggerakkan, membimbing dan mengarahkan para personel secara tepat niscaya akan bisa membawa sekolah pada keberhasilan yang optimal.

Sedangkan manajemen kepala sekolah sesungguhnya berhubungan dengan kecakapan, keterampilan dan tingkat pengaruh yang dimiliki seseorang, karena itu manajemen kepala sekolah bisa saja dimiliki orang

${ }^{1}$ Suyanto dan MS Abbas, Wajah dan Dinamika Pendidikan Anak Bangsa, (Yogyakarta: Adicita Karyanusa, 2001, h.63.

${ }^{2}$ Undang-undang Sistem Pendidikan Nasional No. 20 tahun 2003. 
yang yang bukan kepala sekolah. Sedangkan konsep memimpin digunakan dalam konteks hasil peran seseorang khususnya kepala sekolah dalam kelembagaan pendidikan tertentu yang berkaitan dengan kemampuan mempengaruhi orang lain melalui berbagai cara.

Manajemen adalah proses mempengaruhi dalam menentukan tujuan organisasi, memotivasi seluruh SDM sekolah untuk mencapai tujuan dan memperbaiki kelompok dan budaya. Selain itu mempengaruhi prestasi didalamnya, pengorganisasian dan aktivitas untuk mencapai sasaran, memelihara hubungan kerja sama kelompok dan perolehan dukungan dari orang-orang diluar kelompok atau organisasi. ${ }^{3}$

Kepala sekolah harus memiliki kreatifitas, yakni kemampuan untuk mentransformasikan ide dan imajinasi serta keinginan-keinginan besar menjadi sebuah kenyataan. Kreatif dalam berimajinasi, memiliki kekuatan ide melahirkan sesuatu yang baru dan berusaha menampilkan ide-ide karya kreatif, karena ide dan gagasan tanpa karya hanya akan menghasilkan mimpimimpi indah tanpa membawa perubahan, demikian halnya karya tanpa gagasan akan menghasilkan stagnasi dan kejumudan.

Kepala sekolah mempunyai peran yang sangat besar dalam meningkatkan seluruh SDM, memicu semangat kerja dan kerjasama yang harmonis, minat terhadap pengembangan dunia pendidikan, pengembangan kualitas profesional guru-guru termasuk menentukan corak kualitas peserta didik yang dipimpinnya.

Manajemen merupakan hal yang sangat penting untuk mencapai tujuan organisasi. Manajemen adalah suatu kekuatan penting dalam rangka pengelolaan, karenanya kemampuan memimpin secara efektif merupakan kunci keberhasilah organisasi/sekolah. Seorang kepala sekolah juga harus mampu menciptakan iklim dan suasana yang kondusif, aman, nyaman, tenteram, menyenangkan dan penuh semangat dalam bekerja bagi pekerja dan pelajar. Sehingga pelaksanaan kegiatan belajar mengajar dapat berjalan tertib dan lancar dalam mencapai tujuan yang diharapkan. Dengan demikian setiap kepala sekolah harus mampu mempengaruhi, membimbing, mengkoordinir dan menggerakkan orang lain yang ada hubungannya dengan pengembangan ilmu pendidikan serta pengajaran supaya aktivitas-aktivitas yang dijalankan dapat lebih efektif dan efisien dalam pencapaian tujuan pendidikan dan pengajaran. ${ }^{4}$

Oleh karena itu kepala sekolah merupakan personil yang bertanggung jawab terhadap seluruh kegiatan sekolah. Kepala sekolah memiliki wewenang dan tanggungjawab penuh dalam meneyelenggarakan kegiatan

\footnotetext{
${ }^{3}$ Mulyadi, Manajemen Kepala Sekolah dalam Meningkatkan Budaya Mutu, (Malang: UIN Press, 2010), h. 1.

${ }^{4}$ Hendyat Soetopo, Pengantar Oprasional Administrasi Pendidikan, (Surabaya: Usaha Nasional, 1992, h. 271.
} 
pendidikan sekolah yang dipimpinnya, dengan demikian kepala sekolah perlu dipilih berdasarkan pengangkatan yang profesional, bahkan perlu dipilih dalam kurun waktu tertentu. Hal ini akan dapat menimbulkan iklim yang demokratis disekolah yang akan mendorong iklim yang kondusif dalam mencapai kualitas pembelajaran yang optimal dan perkembangan seluruh potensi peserta didik. ${ }^{5}$

Terkait dengan pelaksanaan kegiatan pendidikan guru merupakan unsur yang sangat penting menentukan ketercapaian program pembelajaran di sekolah. Guru merupakan komponen yang perlu mendapat perhatian, karena baik ditinjau dari segi posisi yang ditempati dalam struktur organisasi pendidikan maupun dilihat dari tugas dan kewajiban yang diemban, guru merupakan pelaksanaan terdepan yang dapat menentukan dan mewarnai proses belajar mengajar serta kualitas pendidikan pada umumnya.

Mengajar pada hakikatnya bukanlah semata persoalan menceritakan sesuatu, begitu juga belajar bukanlah konsekuensi otomatis dari penuangan informasi kedalam bentuk seseorang. Belajar memerlukan keterlibatan mental dan kerja. Karena itu upaya awal yang perlu dilakukan adalah menumbuhkan kesadaran akan pentingnya siswa belajar dan guru mengajar untuk mendapatkan kebermaknaan sehingga efektivitas pembelajaran bisa berwujud dengan optimal.

Kepala sekolah sudah seharusnya memfungsikan guru sebaik-sebaiknya sebagai bentuk tugas dan tanggungjawab yang besar di dalam merencanakan, mengorganisir, membina, melaksanakan, serta mengendalikan SDM guru dengan memotivasi mereka untuk selalu meningkatkan kreativitas, terlebih dalam menjalankan kegiatan prose belajar mengajar (KBM). Mengingat peraturan Menteri Pendidikan dan Kebudayaan No. 16 tahun 2018 menyebutkan :

Yang tidak kalah pentingnya dalam peran persekolahan adalah Kepala Sekolah. Kepala sekolah bertanggung jawab terhadap keberhasilan proses pembelajaran di sekolah. Pada dasarnya kepala sekolah adalah guru yang diberi tugas tambahan.Semula tugas tambahannya sebagai edukator, manajer, administrator, supervisor, leader, Inovator, dan motivator (Emaslim). Namun berdasarkan Peraturan Pemerintah Nomor 19 tahun 2017 beban kerja Kepala Sekolah sepenuhnya untuk melaksanakan tugas pokok manajerial. Dan pengembangan kewirausahaan, serta supervisi kepada Guru dan tenaga kependidikan. ${ }^{6}$ Guna menindaklanjuti Peraturan Pemerintah tersebut Mendikbud mengeluarkan peraturan Nomor 6 Tahun 2018 tentang Penugasan Guru Sebagai Kepala Sekolah.

\footnotetext{
${ }^{5}$ Peraturan Pemerintah No. 19 tahun 2017 tentang Tugas tambahan Kepala Sekolah.

${ }^{6}$ Peraturan Menteri Pendidikan dan Kebudayaan, No. 6 tahun 2018.
} 
Begitu juga guru sebagai salah satu komponen dalam KBM memiliki sentralitas untuk menentukan keberhasilan pembelajaran. Karena fungsi utama guru ialah merancang, mengelola, melaksanakan dan mengevaluasi pembelajaran. Selain itu kedudukan guru dalam kegiatan pembelajaran juga sangat strategis dan menentukan. Strategis karena guru akan menentukan kedalaman dan keluasan materi pelajaran, dan bersifat menentukan karena guru yang akan menetapkan dan memilih materi yang akan disajikan dalam kegiatan pembelajaran. Maka profesionalitas guru menjadi tuntutan dalam mengimplementasikan kurikulum dan materi pengajaran secara tepat sebagai bentuk profesionalitas kerjanya. ${ }^{7}$

Selain itu guru merupakan komponen yang paling berperan dalam proses dan hasil pendidikan yang berkualitas. Dengan demikian upaya perbaikan apapun yang dilakukan untuk meningkatkan kualitas pendidikan tidak akan memerlukan sumbangan yang signifikan tanpa didukung oleh guru yang profesional dan berkualitas. Dalam arti kata perbaikan kualitas pendidikan harus bermula dari guru dan berujung pada guru pula.

Penjelasan tersebut mengindikasikan adanya bentuk pengakuan akan kedudukan guru sebagai seorang yang mampu mengentaskan kebodohan mengingat substansi spiritualitas moral dan kelangsungan dalam dinamika peradaban dan kelangsungan masyarakat. Guru adalah seorang yang bertanggungjawab dalam mengemban amanah dari sisi agama dan moral.

Untuk mendapatkan mutu guru yang berkualitas tinggi diperlukan konsep strategis pengembangan mutu guru yang ditawarkan oleh para ahli. Abidin menawarkan dua teknik strategi yakni; 1) meningkatkan kemampuan, 2) meningkatkan kesejahteraan. ${ }^{8}$

Fakta menunjukkan bahwa guru di Indonesia belum mampu menunjukkan kinerja (work performance) yang memadai. Hal ini menunjukkan bahwa kinerja guru masih belum dikatakan baik. Oleh karena itu diperlukan berbagai cara untuk meningkatkan kemampuan keterampilan dantentunya semua kompetensi yang seharusnya dimiliki oleh seorang guru demi terwujudnya pembelajaran yang berkualitas. ${ }^{9}$

Pada tingkat pendidikan menengah atas guru merupakan pusat bagi produktifitas dan merupakan faktor utama yang mempengaruhi proses belajar mengajar. Kualitas lulusan pendidikan sering digantungkan pada peran guru dan pengelola komponen yang terkait dalam dunia pendidikan.

\footnotetext{
${ }^{7}$ Syarifudin Nurdin, Guru Profesional dan Implementasi Kurikulum, (Jakarta: Ciputat Press Cet. III, 2009), h. vi.

${ }^{8}$ Abidin ZS, Pengembangan sumber daya Manusiadan Tantangannya dalam PJPT II, (Malang: FIA Unibraw, 2007), h. 22.

${ }^{9}$ Mulyasa, Menjadi Kepala Sekolah Profesional, (Bandung: PT Remaja Rosdakarya, 2008), h. vii.
} 
Perbaikan kompetensi berkelanjutan harus menjadi salah satu strategi peningkatan kompetensi pendidikan, hal ini diharapkan dapat mengatasi rendahnya mutu pendidikan yang tidak hanya mengandalkan pendekatan yang bersifat konvensional melainkan melalui optimalisasi sumberdaya dan sumber dana yang secara langsung dapat meningkatkan kualitas pendidikan. $^{10}$

Pemberlakuan Undang-undang nomor 20 tahun 2003 Bab XIV pasal 51 ayat 1 tentang sistem pendidikan nasional yang mengamanatkan bahwa "pengelolaan pendidikan anak usia dini, sekolah dasar, menengah dan menengah atas dilaksanakan berdasarkan standar pelayanan minimal dengan prinsip manajemen berbasis sekolah". 11

Pendidikan termasuk produk jasa yang memiliki ketetapan standar kualitas yang harus dicapai seiring dengan perjalanan dan perkembangannya. Standar tersebut tertuang pada Peraturan Pemerintah Nomor 19 tahun 2005 bahwa kualitas pendidikan Indonesia diukur melalui delapan standar yakni; standar isi, proses, kompetensi lulusan, pendidikan dan tenaga kependidikan, sarana dan prasarana, pengelolaan, pembiayaan dan standar penilaian. ${ }^{12}$ Dengan demikian ukuran pencapaian kualitas pendidikan sangat ditentukan oleh masing-masing sekolah. Jadi dapat diketahui bahwa dalam rangka pengembangan sumberdaya guru yang berkompetensi pada sebuah lembaga pendidikan diperlukan metode, bentuk, teknik dan upaya strategis untuk mengatasi problem penurunan pendidikan dan dikhawatirkan berimplikasi terhadap kualitas pendidikan.

Penelitian ini dilaksanakan di Madrasah Aliyah Muhammadiyah (MAM) yang beralamat di Desa Kampung Delima Kecamatan Curup Utara, untuk menggali jawaban terhadap persoalan manajemen kepala sekolah dari realisasi proses perencanaan, pengorganisasian, pelaksanaan dan pengawasan dalam mengembangkan kompetensi guru pendidikan agama Islam yang ada di sana.

Madrasah Aliyah Muhammadiyah (MAM) merupakan salah satu lembaga pendidikan tingkat sekolah menengah atas yang berada di Kecamatan Curup Utara Kabupaten Rejang Lebong Provinsi Bengkulu dimana penduduknya mayoritas menganut agama Islam memberi kesan teguh pada tradisi dan kebudayaan sehingga terkesan lebih konservatif. MAM bertujuan untuk membina, menumbuhkan meningkatkan seluruh potensi anak secara optimal sehingga terbentuk prilaku dan kemampuan

\footnotetext{
${ }^{10}$ Ibid., h. 83 .

${ }^{11}$ Undang-Undang Republik Indonesia, Nomor 20 tahun 2003 tentang Sistem Pendidikan Nasional, h. 33.

${ }^{12}$ Doni Juni Priansa, Manajemen Supervisi dan Manajemen Kepala Sekolah, (Bandung: Alfabeta, 2014) h. 26,27.
} 
dasar sesuai dengan tahap perkembangannya agar memiliki kesiapan untuk memasuki pendidikan selanjutnya.

Berdasarkan pengamatan dan observasi peneliti, Kepala Madrasah Aliyah Muhammadiyah beberapa tahun terakhir ini melalui manajemen kepala sekolah yang ada sudah mulai mengadakan perubahan untuk meningkatkan kompetensi guru. Tetapi pada sisi lain belum adanya guru yang memiliki prestasi pada bidangnya dan belum ada peningkatan minat para guru untuk lebih memperbaiki profesionalitas dirinya melalui pelatihan-pelatihan.

\section{Manajemen Kepala Sekolah dalam Meningkatkan Kompetensi Guru Pendidikan Agama Islam di MAM Curup}

Berdasarkan dari hasil wawancara yang telah peneliti lakukan di MAM Curup bahwa ada berbagai strategi kepala sekolahdalam meningkatkan kompetensi profesional guru Pendidikan Agama Islam (PAI). Strategi yang dilakukan terbagi ke dalam dua kegiatan, yaitu formal dan informal. Seperti yang di ungkapkan oleh Hamidah, S.Ag., M.Ag. bahwa: "Di MAM Curup ini strategi dalam meningkatkan kompetensi guru PAI itu terbagi dalam dua kegiatan, yaitu kegiatan formal dan nonformal. Kenapa demikian, karena kalau guru ini terus menerus mengikuti kegiatan yang sejenis tentunya akan menimbulkan rasa bosan atau jenuh, nantinya takut jika dampaknya mereka itu tidak menerima ataupun menyerap apa-apa yang telah disampaikan oleh narasumber, misalnya dalam kegiatan seminar, penataran, dan lain sebagainya. Jadi mereka selain mengikuti ataupun mengadakan kegiatan peningkatan kompetensi guru yang sifatnya formal, juga mengadakan kegiatan-kegiatan non formal, diantaranya mengadakan sharing dengan para guru, kapanpun mereka bebas datang ke ruangan Kepala Sekolah untuk sharing, kemudian juga sering diberi motivasi kepada guru PAI terkait dengan kompetensi mereka, sealin itu kedisiplinan juga selalu diutamakan, dan dicontohkan, misalnya suatu hal yang kecil yaitu tiba disekolah upayakan lebih awal, masuk kelas tepat waktu demikian juga ketika keluar atau pada jam istirahat. Di samping beberapa hal di atas masih banyak kegiatan-kegiatan lain yang dicontoh".

Senada dengan apa yang disampaikan Yuni Wizia, guru PAI; "Kepala sekolah selain memberi kesempatan kepada guru untuk mengikuti kegiatan pelatihan, seminar, woskshop dan diskusi antar guru, kepal sekolah

\footnotetext{
${ }^{13}$ Hasil wawancara dengan Ibuk Hamidah kepala MAM Curup, 05 Juli 2019.
} 
sangat senang difatangi untuk kordinasi dan sharing terkait kegiatan belajar mengajar di sekolah." 14

Hal serupa disampaikan oleh siswa: "bahwa guru PAI pernah menceritakan bahwa kepala sekolah sangat terbuka kepada keluarga sekolah termasuk guru, staf, wali murid dan juga siswa, sepanjang untuk memperbaiki sekolah kemasa depan". ${ }^{15}$

Berdasarkan wawancara dengan Kepala MAM Curup Strategi yang dilakukan oleh Kepala Sekolah, yaitu:

\section{Strategi Formal:}

a. Pelatihan, diklat dan seminar guru yang berkaitan dengan Pendidikan Islam

Berdasarkan hasil interview yang telah peneliti lakukan di MAM Curup, sering mengikutkan guru pendidikan agama Islam (PAI) dalam pelatihan, seminar, diklat dan jugastudy banding ke lembaga Islam lain dalam rangka meningkatkanprestasi dan wawasan tentang pendidikan agama Islam. Seperti yang diungkapkan oleh Hamidah kepala sekolah bahwa:"Strategi yang saya lakukan dalam meningkatkan kompetensi profesional guru PAI yaitu mengikutkan guru PAI untuk pendidikan dan latihan (Diklat), pelatihan dan seminar yang berkaitan dengan pendidikan agama khususnya. Dan juga pernah dilaksanakan study banding ke lembaga Islam lain dengan tujuan untuk terus meningkatkan mutu pendidikan agama Islam di MAM Curup.". ${ }^{16}$

Pernyataan tersebut sama halnya dengan yang dikatakan oleh Ibuk Yuli Aryani Putri wakil kepala bidang kurikulum mengatakan, bahwa:"Begini pak, dalam pelatihan atau seminar, kepala sekolah selalu mengikutkan guru PAI, dan juga mengikutsertakan guru PAI untuk study banding ke lembaga Islam lain, terutama yang berkenaan dengan masalah PAI.". ${ }^{17}$

Suminarti menyebutkan: "Kepala sekolah mengikutkan guru PAI, staf karyawan untuk ikut studi banding ke Madrasah Aliyah Negeri (MAN) Model di Bengkulu, guna untuk menambah ilmu dan wawasan terkait kegiatan belajar mengajar dan ekstrakurikuler". ${ }^{18}$ Di MAM Curup antara lain strategi yang dilakukan kepala sekolah dalam meningkatkan kompetensi profesional guru PAI adalah: mengikutserta guru dalam diklat,pelatihan,

\footnotetext{
${ }^{14}$ Hasil Wawancara dengan Ibuk Yuni Wizia guru PAI MAM Curup, 05 Juli 2019.

${ }^{15}$ Hasil Wawancara dengan Agung Pramudani, siswa kelas 11 MAM Curup, 06 Juli 2019.

${ }^{16}$ Hasil Wawancara dengan Ibuk Hamidah Kepala Sekolah MAM Curup,10 Mei 2019. Mei 2019.

${ }^{17}$ Hasil Wawancara dengan Ibuk Yuli Aryani Putri Waka Kurikulum MAM Curup,11

${ }^{18}$ Hasil Wawancara dengan Ibuk Suminarti Guru PAI MAM Curup, 11 Mei 2019.
} 
seminar, dan study banding ke lembaga Islam lain serta sering diadakan sharing terhadap guru PAI.

b. Supervisi

Supervisi dilakukan dengan tujuan untuk mengembangkankemampuan dalam proses belajar mengajar. Pelaksanaan supervisidi MAM Curup dilakukan oleh dua orang yangterdiri dari Ibuk Hamidah, selaku kepala sekolahdengan orang yang bisa dipercaya dalam hal ini diserahkan kepadaIbuk Yuli Aryani Putri selaku wakil kepala bidang kurikulum, mereka bersamamelakukan supervisi tiap semester.

Dalam meningkatkan kompetensi guru PAI, kepala sekolah mendorong guru untuk kreatif dan inovatif dengan melakukanbeberapa pendekatan terhadap guru-guru dan staf khususnya guru PAI yang berada di MAM Curup. Pendekatan-pendekatan itu dilakukan dengan cara mengakrabkan diri denganguru, misalnya berkunjung ke ruang guru, sesuai dengan penuturan dari Hamidah selaku kepala sekolah mengatakan, bahwa: "Setiap hari ke sekolah, dan mendekati guru kemudian berkunjung ke ruang guru biasanya saya menanyakan ada kabar terbaru apa yang tidak saya ketahui, terus siapa yang tidak masuk, tidak hanya kepada guru, tetapi pada karyawan di MAM Curup juga. Selain itu para guru ataupun staf karyawan diberi kesempatan sewaktu-waktu untuk datang ke ruangan kepala sekolah, jika ada uneg-uneg ataupun suatu hal yang ingin disampaikan. Itu merupakan kunci keakraban dengan guru maupun staf karyawan, selain itu ketika bertemu, berpapasan selalu bertegur sapa ini menunjukkan hubungan yang baik antara atasan dan bawahan."19

Dari hasil interview yang peneliti lakukan menunjukkanbahwa kepala sekolah menjalin hubungan baik dengan para guru danstaf karyawan di MAM Curup. Sikap Hamidah tersebut, menjadi motivasi bagi guru-guru dan juga guru menjadi merasa diperhatikan oleh kepala sekolah sehingga jika ada permasalahan guru tidak segan untuk membicarakannya dengan kepala sekolah,

\section{Strategi Non formal :}

a. Kedisiplinan

MAM Curup selalu mengedepankan kedisiplinan baik untuk peserta didik maupun gurunya. Kedisiplinan dimulai dari Hamidah yang menjabat sebagai kepala sekolah. Hamidah biasanya berangkat lebih pagi dari guruguru yang lain, berangkat lebih awal dan pulang belakangan. Seperti yang dipaparkan oleh Yuli Ayani Putri selaku waka kurikulum mengatakan

\footnotetext{
${ }^{19}$ Hasil Wawancara dengan Ibuk Hamidah Kepala Sekolah MAM Curup,15 Mei 2019.
} 
bahwa: "Sikap Ibuk Hamidah sendiri yang sangat disiplin berangkat lebih awal dan pulang lebih akhir, membuat guru-guru yang lain jadi segan dan turut disiplin. Kalau ada guru yang tidak masuk mengajar guru tersebut wajib memberi surat izin beserta alasan yang tepat dan wajib memberi tugas pada siswa. Jadi meski guru tidak hadir siswa tetap bisa melakukan proses pembelajaran sebagaimana mestinya". ${ }^{20}$

Karena sikap kepala sekolah yang demikian, guru-guru menjadi rajin dan segan jika datangnya terlambat. Kedisiplinan tidak hanya ditujukan pada peserta didik akan tetapi guru juga perlu ditingkatkan kedisiplinannya karena guru sebagai contoh bagi peserta didiknya.

b. Memotivasi guru

Meningkatkan kompetensi guru pendidikan agama Islam membutuhkan motivasi dan dukungan dari berbagai pihak, seperti halnya motivasi dari kepala sekolah. Seperti yang di ungkapkan oleh Siti Nazirah selaku guru Pendidikan Agama Islam yang mengatakan bahwa: "Ibuk kepala sekolah selalu mendorong atau memberikan motivasi kepada guru pendidikan agama Islam, untuk lebih kreatif dan inovatif dalam proses pembelajaran di kelas. Dengan motivasi dari kepala sekolah seperti itu, maka guru pendidikan agama Islam menjadi semangat dalam menjalankan tugasnya. Selain itu guru di tuntut untuk membuat rencana kegiatan mutu PAI dalam waktu jangka pendek yaitu satu tahun, lalu kepala sekolah yang merealisasikannya. Hal ini juga termasuk cara memotivasi diri untuk terus meningkatkan kompetensi, agar nantinya juga dapat menghasilkan lulusan yang berprestasi.". 21

Dorongan atau motivasi tidak hanya datang dari kepala sekolah akan tetapi juga datang dari guru pendidikan agama Islam memotivasi dirinya sendiri untuk meningkatkan kompetensi.

\section{Hambatan dan Solusi Manajemen Kepala Sekolah dalam Meningkatkan Kompetensi Guru Pendidikan Islam di MAM Curup}

Dalam menjalankan strategi-strategi tersebut di atas, ada beberapa hambatan yang ditemui. Seperti yang dikemukakan oleh Hamidah selaku kepala sekolah MAM Curup yang mengatakan bahwa: "Ada beberapa hambatan yang kami temui dalam meningkatkan kompetensi guru,

Pertama, kurangnya perhatian orang tua siswa pada saat di rumah, rata-rata siswa orang tuanya sibuk bekerja, jadi kemungkinan besar pada saat Mei 2019.

${ }^{20}$ Hasil Wawancara dengan Ibuk Yuli Aryani Putri Waka Kurikulum MAM Curup,18

${ }^{21}$ Hasil Wawancara dengan Ibuk Siti NazirahGuru PAI MAM Curup, 20 Mei 2019. 
di rumah siswa-siswa ini kurang diperhatikan dari segi tugas-tugas sekolahnya.

Kedua, tabrakannya waktu pelatihan dengan waktu mengajar guru, sehingga guru harus memilih antara mengajar atau ikut pelatihan.

Dalam hal ini kepala sekolah memberikan solusi, pertama, mengajak wali siswa bermusyawarah agar terlibat dalam kemajuan siswa, dengan cara mengontrol belajar siswa pada saat berada di rumah, kedua, mengadakan kerja sama dengan lembaga-lembaga lain seperti sekolah lain, dinas pemerintahan, kemuhamadiyahan dan perguruan tinggi untuk mengadakan pelatihan-pelatihan yang bertujuan meningkatkan kompetensi guru". ${ }^{22}$

\section{KESIMPULAN}

Manajemen Kepala Sekolah dalam Meningkatkan Kompetensi Guru Pendidikan Agama Islam di MAM Curup adalah: a) Mengikutkan guru dalam diklat, pelatihan, seminar dan study banding, guru PAI di MAM Curup, sering mengikuti pelatihan, seminar, diklat dalam rangka meningkatkan prestasi dan wawasan tentang pendidikan agama Islam, b) Mengedepankan kedisiplinan baik itu untuk peserta didik maupun guru, kedisiplinan itu dimulai kepala sekolah sendiri, c) Memotivasi guru, motivasi dari kepala sekolah menjadi semangat bagi guru untuk meningkatkan perbaikan dalam inovasi pendidikan sebagai wujud nyata mengembangkan kompetensi profesional guru PAI, serta menyiapkan fasilitas proses belajar mengajar, d) Supervisi, pelaksanaan supervisi di MAM Curup dilaksanakan dua orang guru yang terdiri dari Hamidah selaku kepala sekolah dan Yuli Arni Putri selaku wakil kepala bidang kurikulum, mereka bersama melakukan supervisi tiap semester.

Penerapan dari manajemen kepalah sekolah di MAM Curup sudah terlaksana, kompetensi guru PAI di MAM Curup cukup baik, selain melaksanakan tugas pokok guru-guru PAI melaksanakan tugas tambahan seperti kegiatan keagamaan, membuat kelengkapan mengajar sepertiRPP.Diawal tahun ajaran baru membuat program tahunan (prota), setiap semester membuat program semester (promes), silabus, waktu mengajar menggunakan metode yang sesuai dengan materi yang disampaikan agar anak tidak merasa jenuh.

Hambatan manajemen kepala sekolah dalam mengembangkan kompetensi guru PAI di MAM Curup: a) Peran orang tua belum tampak pada pribadi/karakter masing-masing peserta didik, b) bersamaannya waktu

\footnotetext{
${ }^{22}$ Hasil Wawancara dengan Ibuk Hamidah Kepala sekolah MAM Curup, 22 Mei 2019
} 
mengajar guru dengan waktu pelatihan-pelatihan dalam meningkatkan kompetensi guru.

Solusi Manajemen Kepala Sekolah dalam menghadapi hambatan tersebut adalah: a) Kepala sekolah dan guru-guru melaksanakan musyawarah kepada wali siswa agar selalu terlibat dalam memantau kemajuan siswa, b) Sekolah menjalin kerjasama dengan berbagai instansi pendidikan baik dengan sekolah lain, dinas pemerintah, kemuhammadiyahan, ataupun dengan perguruan lain sehingga dapat dimanfaatkan sebagai sarana pelatihan bagi para guru.

\section{DAFTAR PUSTAKA}

Abidin ZS, Pengembangan sumber daya Manusiadan Tantangannya dalam PJPT II, Malang: FIA Unibraw, 2007

Arief Subyantoro dan FX Suwarto, Metode Dan Teknik Penelitian Sosial, Yogyakarta: Andi, 2006

Doni Juni Priansa, Manajemen Supervisi dab Manajemen Kepala Sekolah, Bandung: Alfabeta, 2014

Hendyat Soetopo, Pengantar Oprasional Administrasi Pendidikan, (Surabaya: Usaha Nasional, 1992

Irawan Soehartono, Metodologi Penelitian Sosial, Bandung: Remaja Rosdakarya, 2004

Lexy J Meleong, Metodologi Penelitian Kualiatatif, Bandung: Remaja Rosdakarya, 2010

Luk-luk Nur Mufidah, Supervisi Pendidikan, Jember: Center for Society Studies, 2008

Mulyadi, Manajemen Kepala Sekolah dalam Meningkatkan Budaya Mutu, Malang: UIN Press, 2010

Mulyasa, Menjadi Kepala Sekolah Profesional, Bandung: PT Remaja Rosdakarya, 2008

Sudarwan Danim, Profesionalisasi dan Etika Profesi Guru, Bandung: Alfabeta, 2010

Sugiyono, Metode Penelitian Pendidikan: Pendekatan Kuantitatif, Kualitatif, dan $R \& D$, Bandung: Alfabeta, 2013

Sugiyono, Metode Penelitian Pendidikan: Pendekatan Kuantitatif, Kualitatif, dan R\&D, Bandung: Alfabeta, 2013

Sugiyono, Statistik Untuk Penelitian, Bandung: Alfabeta, 2011

Suharsimi Arikunto, Prosedur Penelitian, Jakarta: Rineka Cipta, 2010

Suyanto dan MS Abbas, Wajah dan Dinamika Pendidikan Anak Bangsa, Yogyakarta: Adicita Karyanusa, 2001

Syaiful Sagala , Kemampuan Profesional dan Guru dan Tenaga Kependidikan, Bandung: Alfabeta, 2009 
130 | Fokus : Jurnal Kajian Keislaman dan Kemasyarakatan, Vol 4, No. 2, Nov 2019

Syarifudin Nurdin, Guru Profesional dan Implementasi Kurikulum, Jakarta: Ciputat Press Cet. III, 2009

Peraturan Menteri Pendidikan dan Kebudayaan, No. 6 tahun 2018.

Undang-Undang Republik Indonesia, Nomor 20 tahun 2003 tentang Sistem Pendidikan Nasional, h. 33.

Undang-undang Sisdiknas No. 20 tahun 2003 